The Dynamics of Language and Inequality in Education 
NEW PERSPECTIVES ON LANGUAGE AND EDUCATION

Founding Editor: Viv Edwards, University of Reading, UK

Series Editors: Phan Le Ha, University of Hawaii at Manoa, USA and Joel Windle, Monash University, Australia.

Two decades of research and development in language and literacy education have yielded a broad, multidisciplinary focus. Yet education systems face constant economic and technological change, with attendant issues of identity and power, community and culture. This series will feature critical and interpretive, disciplinary and multidisciplinary perspectives on teaching and learning, language and literacy in new times.

All books in this series are externally peer-reviewed.

Full details of all the books in this series and of all our other publications can be found on http://www.multilingual-matters.com, or by writing to Multilingual Matters, St Nicholas House, 31-34 High Street, Bristol BS1 2AW, UK. 


\section{The Dynamics of}

\section{Language and}

Inequality in

Education

\section{Social and Symbolic Boundaries in the Global South}

Edited by

Joel Austin Windle, Dánie de Jesus and Lesley Bartlett 
DOI https://doi.org/10.21832/WINDLE6942

Library of Congress Cataloging in Publication Data

A catalog record for this book is available from the Library of Congress.

Names: Windle, Joel A., editor. | Jesus, Dánie Marcelo de, editor. |

Bartlett, Lesley, editor.

Title: The Dynamics of Language and Inequality in Education: Social and Symbolic Boundaries in the Global South/Edited by Joel Austin Windle, Dánie de Jesus and Lesley Bartlett.

Description: Bristol; Blue Ridge Summit: Multilingual Matters, [2020] |

Series: New Perspectives on Language and Education: 77 | Includes bibliographical references and index. | Summary: 'This book contributes new perspectives from the global south on the ways in which linguistic and discursive boundaries shape inequalities in educational contexts, ranging from Amazonian missions to Mongolian universities, using critical ethnographic and sociolinguistic analyses' - Provided by publisher.

Identifiers: LCCN 2019037516 (print) | LCCN 2019037517 (ebook) | ISBN 9781788926942 (hardback) | ISBN 9781788926935 (paperback) | ISBN 9781788926959 (pdf) | ISBN 9781788926966 (epub) | ISBN 9781788926973 (kindle edition)

Subjects: LCSH: Language and education - Developing countries - Case studies.

| Educational equalization - Developing countries - Case studies.

Classification: LCC P40.85.D44 D96 2020 (print) | LCC P40.85.D44 (ebook)

| DDC $306.44-\mathrm{dc} 23$

LC record available at https://lccn.loc.gov/2019037516

LC ebook record available at https://lccn.loc.gov/2019037517

British Library Cataloguing in Publication Data

A catalogue entry for this book is available from the British Library.

ISBN-13: 978-1-78892-694-2 (hbk)

ISBN-13: 978-1-78892-693-5 (pbk)

\section{Multilingual Matters}

UK: St Nicholas House, 31-34 High Street, Bristol BS1 2AW, UK.

USA: NBN, Blue Ridge Summit, PA, USA.

Website: www.multilingual-matters.com

Twitter: Multi_Ling_Mat

Facebook: https://www.facebook.com/multilingualmatters

Blog: www.channelviewpublications.wordpress.com

Copyright (C) 2020 Joel Austin Windle, Dánie de Jesus, Lesley Bartlett and the authors of individual chapters.

All rights reserved. No part of this work may be reproduced in any form or by any means without permission in writing from the publisher.

The policy of Multilingual Matters/Channel View Publications is to use papers that are natural, renewable and recyclable products, made from wood grown in sustainable forests. In the manufacturing process of our books, and to further support our policy, preference is given to printers that have FSC and PEFC Chain of Custody certification. The FSC and/or PEFC logos will appear on those books where full certification has been granted to the printer concerned.

Typeset by Riverside Publishing Solutions.

Printed and bound in the UK by the CPI Books Group Ltd.

Printed and bound in the US by NBN. 